\title{
Physiological Response of Late Sown Wheat to Exogenous Application of Silicon
}

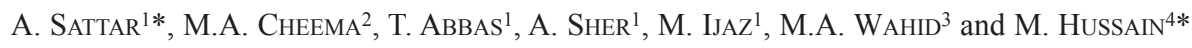 \\ ${ }^{1}$ College of Agriculture, BZU, Bahadur Sub-Campus Layyah, Pakistan \\ ${ }^{2}$ Grenfell Campus - Boreal Ecosystems Research Initiative, Memorial University of Newfoundland, \\ Corner Brook, NL, Canada \\ ${ }^{3}$ Department of Agronomy, University of Agriculture, Faisalabad, Pakistan \\ ${ }^{4}$ Department of Agronomy, Faculty of Agriculture Science and Technology, BZU, Multan, Pakistan
}

(Received 29 May 2016; Accepted 29 August 2016;
Communicated by A. Goyal and A. Pécsváradi)

Late planting of wheat in rice-wheat cropping system is perhaps one of the major factors responsible for low crop yield. The main cause of reduction in yield is due to supra-optimal conditions during the reproductive growth. High temperature during reproductive phase induces changes in water relations, decreases photosynthetic rate, and transpiration rate, stomatal conductance and antioxidative defence system. Silicon ( $\mathrm{Si})$, being a beneficial nutrient not only provides significant benefits to plants growth and development but may also mitigate the adversities of high temperature. A field study was conducted at Agronomic Research Area of University of Agriculture; Faisalabad, Pakistan to assess the performance of late sown wheat with the soil applied Si. Experiment was comprised of three sowing dates; $10^{\text {th }}$ Nov (normal), $10^{\text {th }}$ Dec (late), $10^{\text {th }}$ Jan (very late) with two wheat varieties (Sehar-2006 and Faisalabad-2008), and an optimized dose of Si (100 mg per kg soil), applied at different growth stages (control, crown root, booting and heading). Results indicated that $100 \mathrm{mg} \mathrm{Si}$ per kg soil at heading stage offset the negative impact of high temperature and induced heat tolerance in late sown wheat. Silicon application improved $34 \%$ relative water contents (RWC), 30\% water potential, $26 \%$ osmotic potential, $23 \%$ turgor potential and $21 \%$ photosynthetic rate, and $32 \%$ transpiration rate and $20 \%$ stomatal conductance in wheat flag leaf than control treatment. Further it was observed that $\mathrm{Si}$ application preventing the oxidative membrane damage due to enhanced activity of antioxidant enzymes, i.e. $35 \%$ superoxide dismutase (SOD) and 38\% catalase (CAT). In conclusion results of this field study demonstrated that soil applied Si (100 mg per kg soil) at heading stage enhanced all physiological attributes of wheat flag leaf. Which in turn ameliorated the adverse effects of high temperature in late sown wheat. Study depicted that Si can be used as a potential nutrient in order to mitigate the losses induced by high temperature stress.

Keywords: silicon, high temperature, antioxidants, water relations, late sown wheat

\footnotetext{
*Corresponding author; E-mails: abdulsattar04@gmail.com; mubashiragr@gmail.com
} 


\section{Introduction}

Delayed seeding of wheat (Triticum aestivum L.) is a major cause of low yield in ricewheat and cotton-wheat cropping systems of South Asia (Iqbal et al. 2002; Hussain et al. 2012a). Delayed seeding affects the growth, yield and quality of wheat because it is documented that after $10^{\text {th }}$ November, each day delay in sowing of wheat decreases grain yield at the rate of $60 \mathrm{~kg} \mathrm{ha}^{-1}$ due to shorter growing period and sub-optimum temperature (Hussain et al. 2012a, b).

Temperature below or above the optimum alters cellular functions and yield of crop. The rising temperature during the later stages of crop growth mainly from pre-heading and post-anthesis should be considered as an important yield limiting factor. Normal physiological processes in the cell play key role in rapid cell division, elongation and differentiation which are adversely affected with high temperature. The steady-state transcript and protein level of many reactive oxygen species (ROS)-scavenging enzymes was found to be elevated by heat stress in the plant (Mittler et al. 2004; Vacca et al. 2004).

Silicon ( $\mathrm{Si}$ ) has been implicated as a quasi-essential element, as an appreciable body of evidence supports the conclusion that $\mathrm{Si}$ often enhances plant growth and development (Epstein 1999). On the other hand, it was reported that soil applied Si increased plant growth variables under stressful conditions (Ma and Yamaji 2006; Liang et al. 2007). Application of $\mathrm{Si}$ increased crop growth by enhancing the photosynthetic efficiency, erectness of leaves and structure of xylem vessels under high transpiration rates due to higher temperature and moisture stress (Hattori et al. 2005). High temperatures can cause production of reactive oxygen species. These ROS induced by heat stress cause cellular damage (Liu and Huang 2000). Lipid peroxidation of these ROS with cellular membrane and pigments reduced permeability biological (Xu et al. 2006). Antioxidant defense mechanism is part of the high thermal stress adaptation and resistance is correlated with the acquisition of thermotolerance. In most cases, the adaptability of plants to different thermal regimes can be considered compensatory because they allow mitigating the effects of temperature change on their metabolic system (Berry and Raison 1981). Crop plants adapted enzymatic detoxification systems to counteract ROS, thereby protecting cells from oxidative damage (Sairam and Tyagi 2004). The coordinate function of antioxidant enzymes such as SOD and catalase help in processing of ROS and regeneration of redox metabolites (Ristic et al. 2008).

However, information is still scant regarding the influences of soil application of $\mathrm{Si}$ on antioxidant activity responsible for scavenging the active oxygen species produced as a result of heat-induced oxidative damage. Therefore; the present study has been proposed to investigate the role of soil applied $\mathrm{Si}$ on water relation, photosynthetic pigment and antioxidant defence mechanism and yield in delayed seeding of wheat.

\section{Materials and Methods}

A field experiment was carried out at Agronomic Research Area, University of Agriculture Faisalabad $\left(31.25^{\circ} \mathrm{N}, 73.09^{\circ} \mathrm{E}\right)$, Pakistan during 2011-2012 and 2012-2013. Climate 
of this region is sub-tropical and soil was sandy clay loam. The experiment was laid out using randomized complete block design (RCBD) in split-split arrangement with three replications. Two wheat varieties (Sehar, 2006 and Faislabad, 2008) were seeded on Nov. 10 Dec. $10^{\text {th }}$ and Jan. 10, and Si was applied at basal dose, crown root, booting and heading stages. Silicon source was calcium silicate. Seeds of two contrasting wheat cultivars, viz. Faisalabad-2008 and Sehar-2006 were used $125 \mathrm{~kg} \mathrm{ha}^{-1}$. Seeding was done in wellpulverized soil with the help of hand drill keeping $25 \mathrm{~cm}$ spaced rows. The net plot size was $1.5 \mathrm{~m} \times 5 \mathrm{~m}$. Irrigation and fertilizers were applied according to the regional recommendations of wheat cultivars. Irrigation was applied through border irrigation method to all the treatments. Quantity of water was measured by using the cutthroat flume. Appropriate plant protection measures were adopted to control weeds infestation. Data on maximum and minimum temperature, were recorded at each crop growth stage were recorded during both the years. For relative water contents, flag leaves $(0.5 \mathrm{~g})\left(\mathrm{W}_{\mathrm{f}}\right)$ were rinsed in water until the weight of the leaves is constant. The saturated leaves were weighed $\left(\mathrm{W}_{\mathrm{S}}\right)$ and then dried for $24 \mathrm{~h}$ at $80{ }^{\circ} \mathrm{C}$ for determination of the dry weight $\left(\mathrm{W}_{\mathrm{d}}\right)$. Relative water contents (RWC) were calculated by the following formula (Barrs and Weatherley 1962):

$$
\operatorname{RWC}(\%)=\left(\mathrm{W}_{\mathrm{f}}-\mathrm{W}_{\mathrm{d}}\right) /\left(\mathrm{W}_{\mathrm{S}}-\mathrm{W}_{\mathrm{d}}\right) \times 100
$$

Water potential $\left(\Psi_{\mathrm{w}}\right)$ of flag leaf was determined by using pressure bomb (Santa Barbara, CA, USA). Same leaf were frozen, thawed, sap expressed, centrifuged at $5000 \times g$ and osmotic potential ( $\Psi_{\mathrm{s}}$ ) was determined with an osmometer (Digital Osmometer, Wescor, Logan, UT, USA). Leaf pressure potential $(\Psi \mathrm{p})$ was computed as a difference of $\Psi_{\mathrm{w}}$ and $\Psi$ s. For the measurement of gas exchange parameters such as photosynthetic rate (A), transpiration rate $(\mathrm{E})$, stomatal conductance three young, healthy and fully developed leaves per plant were selected. Selected leaves were used to place in the chamber of portable apparatus termed as InfraRed Gas Analyzer (IRGA) (Analytical Development Company, Hoddesdon, England). All these readings of above-mentioned physiological attributes were taken at day time from 10.00 to 12.00 a.m. with leaf temperature of 28.4 to $32.4{ }^{\circ} \mathrm{C}$, ambient temperature 22.4 to $27.9^{\circ} \mathrm{C}$ and $352 \mu \mathrm{mol} \mathrm{mol}{ }^{-1}$ ambient $\mathrm{CO}_{2}$ concentrations (Zekri 1991). Total soluble proteins were determined followed by Bradford assay (Bradford 1976) and enzymatic antioxidants were determined by follow the procedure of Chance and Maehly (1955) and Giannopolitis and Ries (1977).

Data collected on all parameters were analyzed statistically by using Fisher's Analysis of Variance technique and Least Significant Difference (LSD) test at 5\% probability level was applied to compare the treatments' means (Steel et al. 1997).

\section{Results}

Relative water contents were significantly reduced by the late sowing of wheat. Maximum RWC was noted in $10^{\text {th }}$ November sowing with soil applied Si at heading stage during 2011-2012 and 2012-2013. In addition, Si applied at same growth stage also enhanced the RWC of flag leave of wheat planted at $10^{\text {th }}$ December and $10^{\text {th }}$ January when compared to 

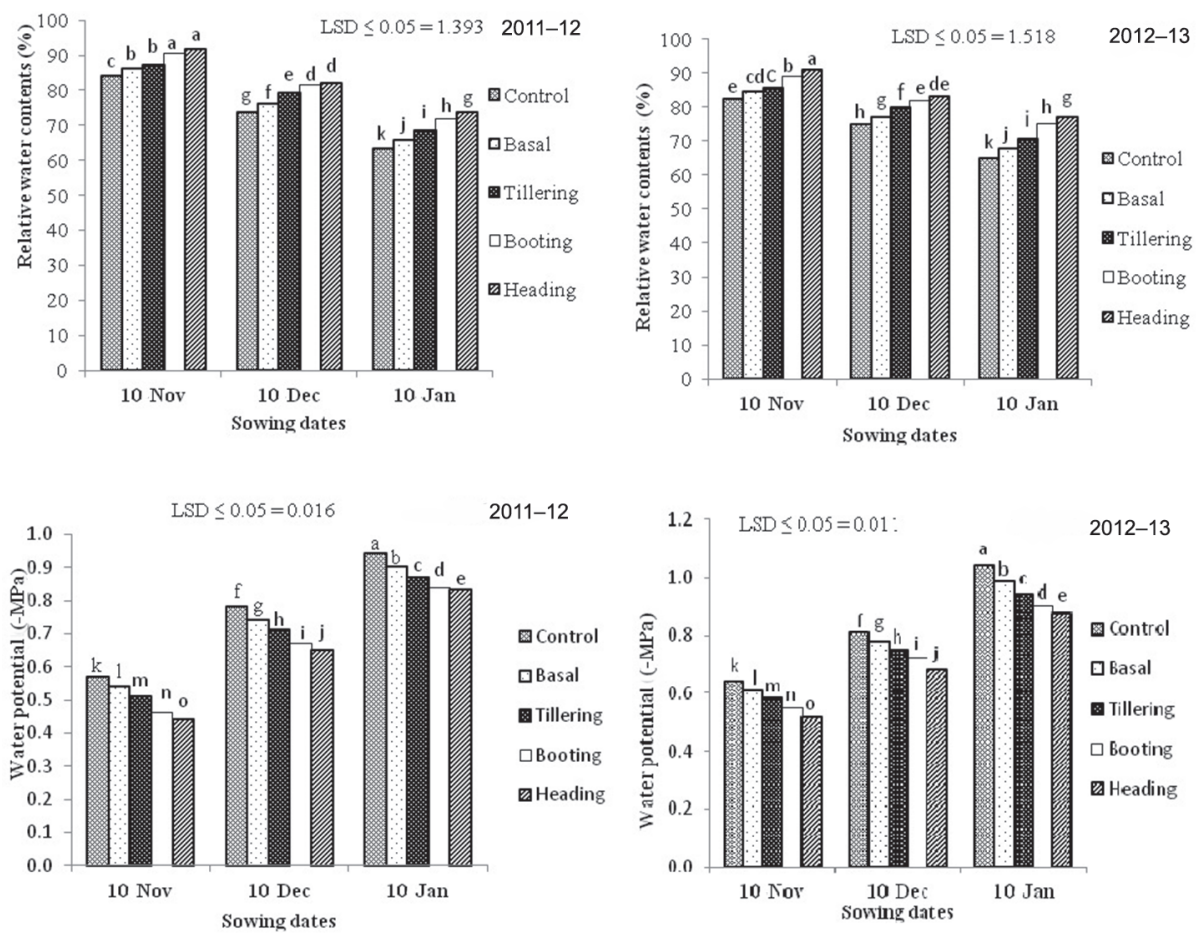

2011-12
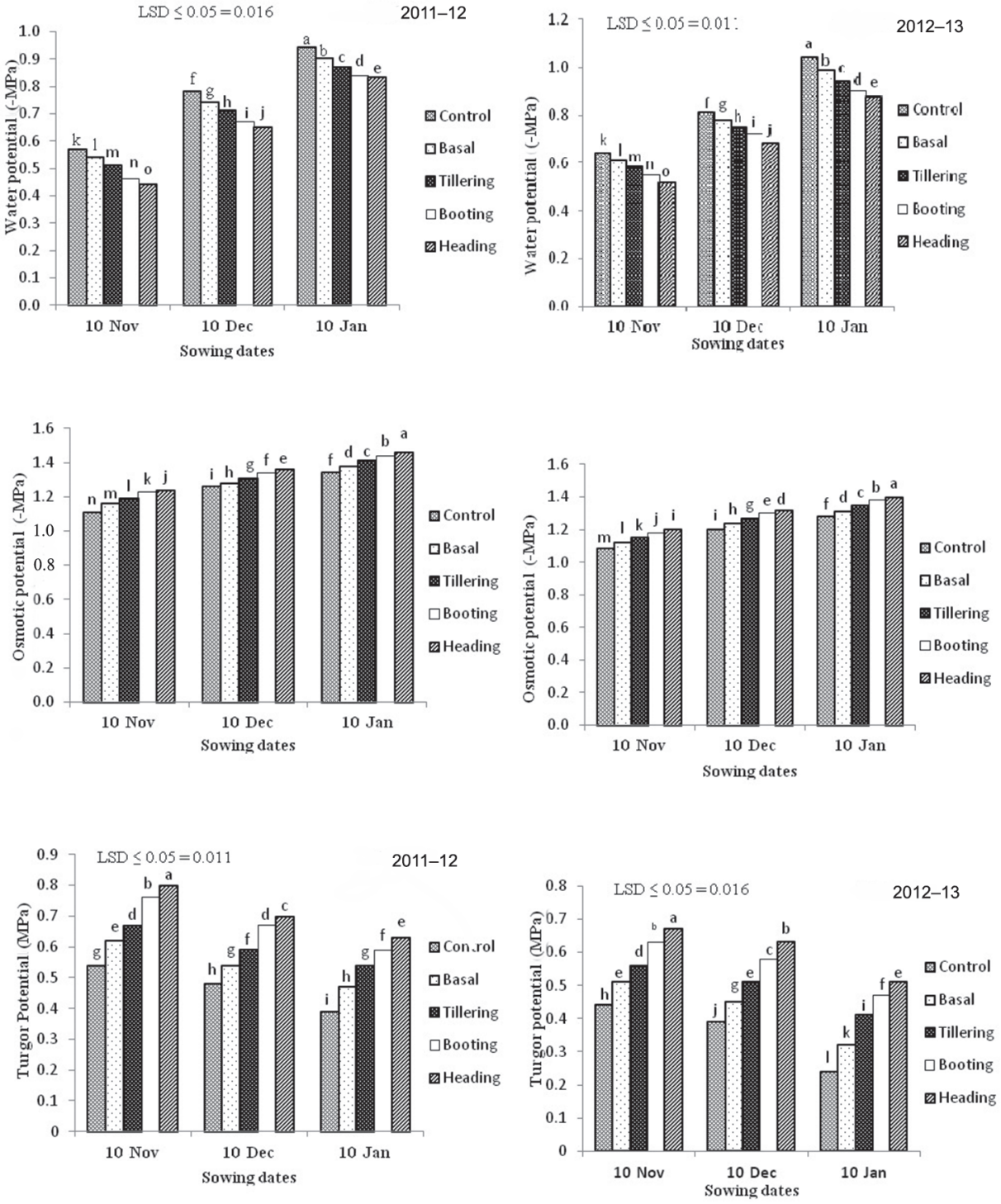
Figure 1. Influence of soil applied Si at various growth stages on water relations of late sown wheat

control and Si applied at other growth stages (Fig. 1). In 2011-2012, data revealed that water potential and osmotic potential became more negative due to late planting of wheat. Soil applied Si improved water and osmotic potential of flag leave of wheat. Less negative water potential was noted in $10^{\text {th }}$ November sowing with soil applied Si at heading stage.
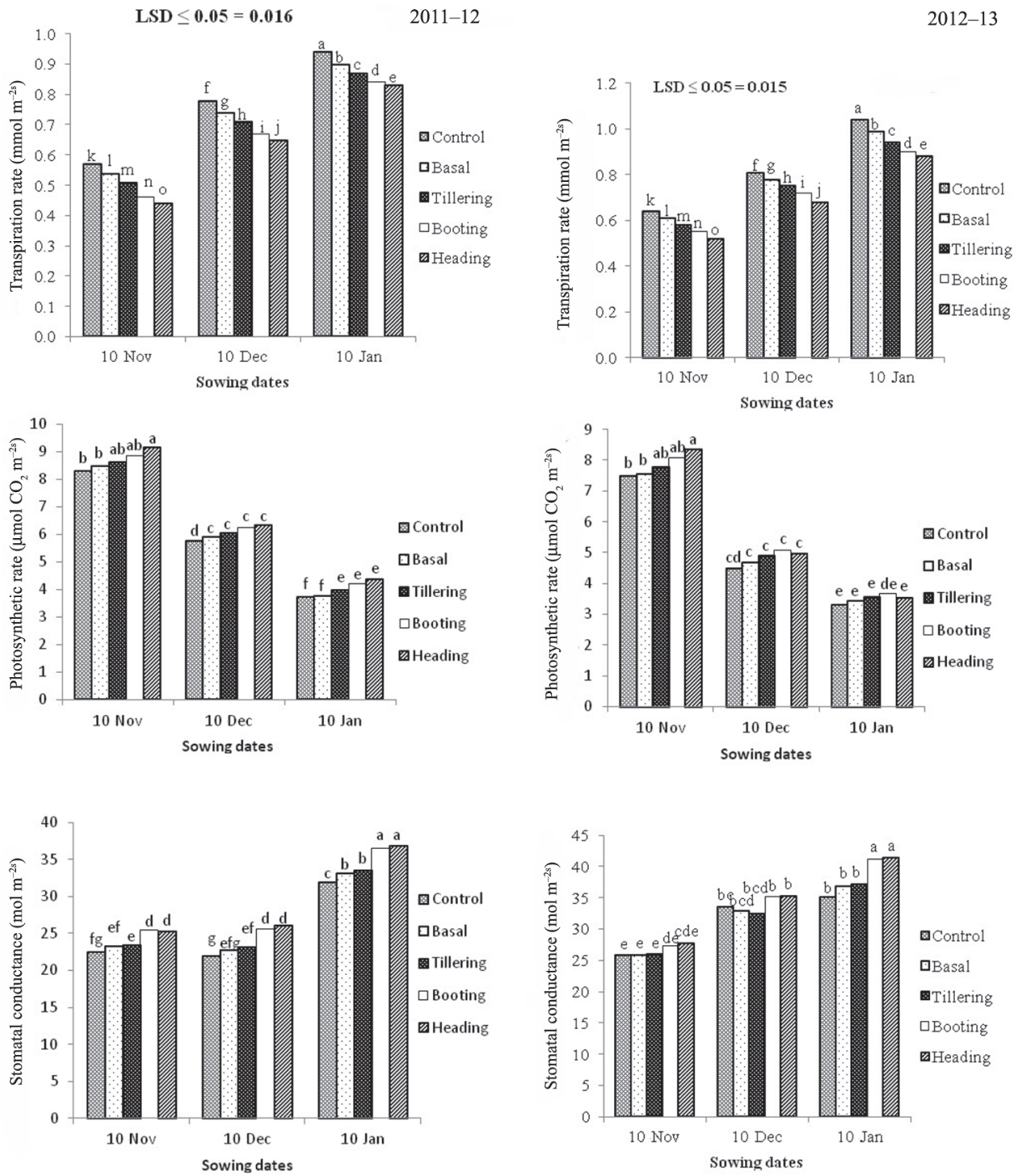

Figure 2. Influence of soil applied $\mathrm{Si}$ at various growth stages on transpiration rate, photosynthetic rate and stomatal conductance of late sown wheat 
In addition, soil applied $\mathrm{Si}$ at same growth stage also enhanced the water potential of flag leave of wheat planted at $10^{\text {th }}$ December and $10^{\text {th }}$ January when compared to control treatment. Almost similar results were observed in second years (Fig. 1). Osmotic potential is increased with soil applied Si at all growth stages of the wheat. Significantly high osmotic potential was recorded in $10^{\text {th }}$ January planted wheat with soil applied $\mathrm{Si}$ at heading stage of the wheat during both year of study. Turgor potential of flag leaf in reduced with delay sowing. Significantly higher turgor potential was recorded when $100 \mathrm{mg}$ Si per $\mathrm{kg}$ soil at heading stage of wheat in $10^{\text {th }}$ November planted wheat. Likewise, soil applied Si at heading stage of $10^{\text {th }}$ December and $10^{\text {th }}$ January planted wheat also significantly improved the turgor potential of flag leaves in 2011-2012 and 2012-2013 (Fig. 1).
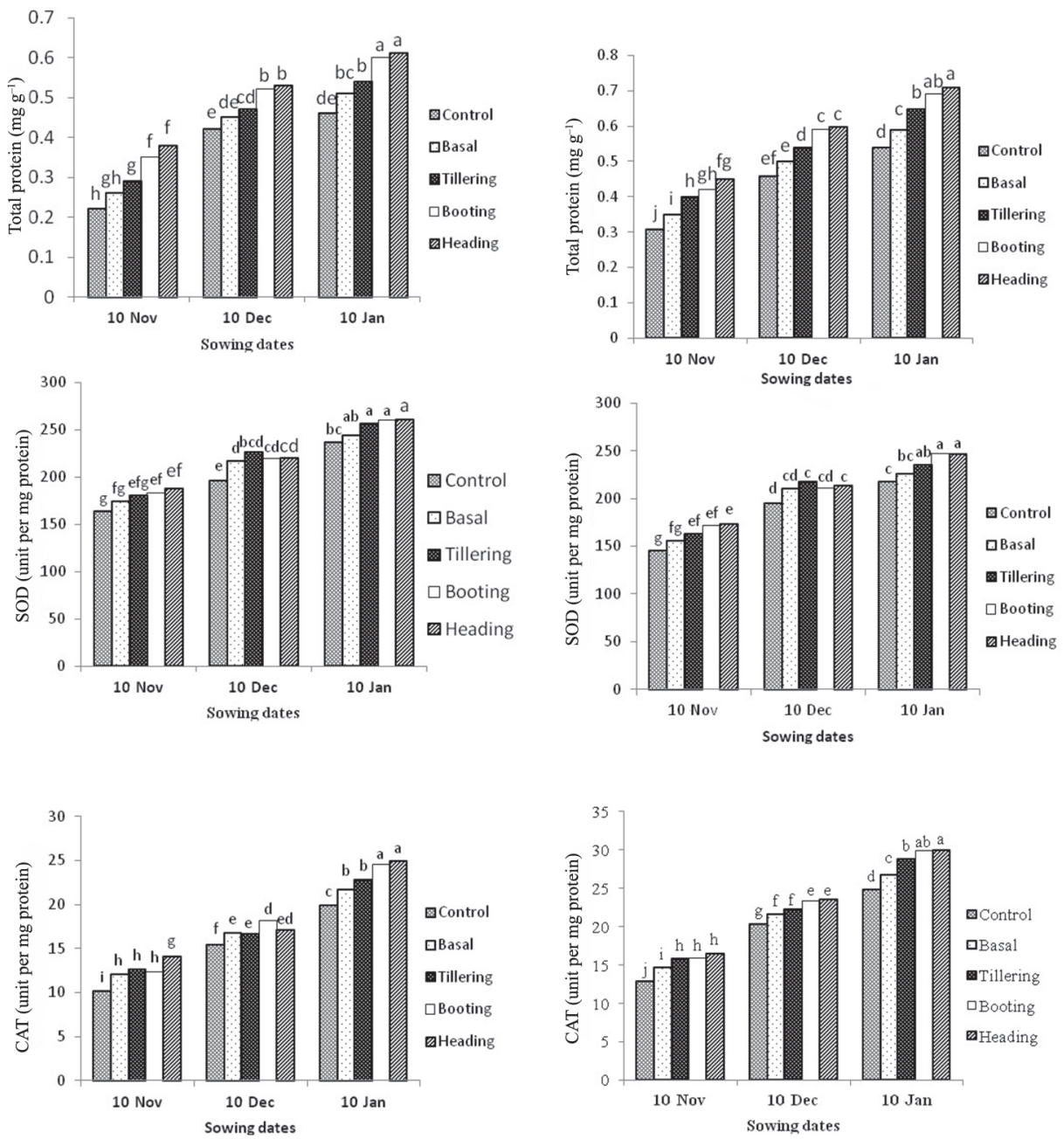

Figure 3. Influence of soil applied Si at various growth stages on total protein and enzymatic antioxidants (unit $\mathrm{mg}^{-1}$ protein) of late sown wheat 
Table 1. Mean maximum and minimum temperature under normal, late and very late planting at different growth stages during 2011-2012 and 2012-2013

\begin{tabular}{|c|c|c|c|c|c|c|c|c|c|}
\hline & \multicolumn{3}{|c|}{ Tillering stage } & \multicolumn{3}{|c|}{ Booting stage } & \multicolumn{3}{|c|}{ Heading stage } \\
\hline & \multicolumn{9}{|c|}{ Temperature $\left({ }^{\circ} \mathrm{C}\right)$ during $2011-2012$} \\
\hline & Max & Min & Means & Max & Min & Means & Max & Min & Means \\
\hline Normal sowing & 20 & 09 & 14.5 & 24 & 18 & 21.0 & 29 & 23 & 26.0 \\
\hline Late sowing & 23 & 16 & 19.5 & 31 & 22 & 26.5 & 37 & 25 & 31.0 \\
\hline Very late sowing & 29 & 18 & 23.5 & 35 & 26 & 30.5 & 42 & 30 & 36.0 \\
\hline \multirow[t]{2}{*}{ Means } & 24.0 & 14.0 & & 30.0 & 22.0 & & 36.0 & 26.0 & \\
\hline & \multicolumn{9}{|c|}{ Temperature $\left({ }^{\circ} \mathrm{C}\right)$ during $2012-2013$} \\
\hline Normal sowing & 18 & 08 & 13.0 & 22 & 15 & 18.5 & 25 & 20 & 22.5 \\
\hline Late sowing & 20 & 14 & 17.0 & 28 & 19 & 23.5 & 30 & 23 & 26.5 \\
\hline Very late sowing & 24 & 16 & 20.0 & 31 & 22 & 26.5 & 37 & 27 & 32.0 \\
\hline Means & 20.5 & 12.5 & & 27.0 & 18.5 & & 30.5 & 23.5 & \\
\hline
\end{tabular}

Statistical analysis revealed that photosynthetic rate, transpiration rate, disturbs stomatal conductance were significantly affected by different sowing dates, varieties and $\mathrm{Si}$ application at various growth stages of wheat during both the years. Early sowing $\left(10^{\text {th }}\right.$ Nov) with Si applied at heading stage gave maximum photosynthetic rate, and transpiration rate, disturbs stomatal conductance which were statistically at par with Si applied at booting stage at same sowing dates (Fig. 2). Similarly under late $\left(10^{\text {th }} \mathrm{Dec}\right)$ and very late $\left(10^{\text {th }} \mathrm{Jan}\right)$ sown conditions, maximum photosynthetic rate, transpiration rate and disturbs stomatal conductance were also recorded when Si was applied at heading stage of wheat when compared to control of each sowing dates where Si was not added to soil during 2011-2012 and 2012-2013 (Fig. 2).

There was a significant effect of sowing dates, wheat cultivars and timing of soil applied Si on total soluble protein of flag leaf of wheat during both the years. Interaction of sowing dates $\times$ Si application was significant during 2011-2012 and 2012-2013. All other interactions were non-significant during both the years (Fig. 3). Comparison of treatments' means showed that maximum total soluble protein was recorded by Si applied at heading stage of wheat under all sowing dates with comparison to control treatment of each sowing date (Fig. 3).

Soil applied Si at various growth stages of wheat significantly enhanced the activity of SOD in both cultivars during the year 2011-2012. Maximum activity of SOD was recorded in Sehar-2006 with Si application at heading stage that was statistically at par with Si applied at booting stage in same cultivar (Fig. 3). Significantly higher activity of SOD and CAT was observed in flag leaf when wheat was sown on $10^{\text {th }}$ of January (very late) and soil applied at heading stage. Similarly Si applied at heading stage of wheat on $10^{\text {th }}$ November and $10^{\text {th }}$ December sowing date gave maximum response when compared to control of these sowing dates during both the years (Fig. 3). 


\section{Discussion}

Water relations are one of the most important factors under changing temperatures (Mazorra et al. 2002). Current study indicates that high temperature due to late sown condition reduced the water relations parameters (Fig. 1). High temperature frequently associated with reduced water availability (Simoes-Araujo et al. 2003) that caused a greater reduction in leaf water potential and turgor potential (Anon et al. 2004). Leaf water potential and its components were changed upon exposure to heat stress (Wahid and Close 2007). High temperature on late sown wheat increased the transpiration rate and caused the water stress in crop pants (Tsukaguchi et al. 2003). Water potential and osmotic potential of plants become more negative due to late sowing of wheat. A number of possible mechanisms are proposed by which Si can increase plant resistance against high temperatures under late sown conditions. Present results revealed that Si application at different stages of wheat significantly increased water relations of late sown wheat (Romero-Aranda et al. 2006). The Si deposited in the tissues of the plant helps to alleviate water stress by reducing transpiration and improves the characteristics of light interception keeping the leaf blade erect (Epstein 1999). Researchers have clearly shown that relative water contents are considerably increased by the application of Si (Agarie et al. 1998). This result was explained by a very thick layer of silica gel associated with the cellulose in the walls of epidermal cells, which can help to reduce water loss, while epidermal cell wall of silica gel allows water to escape at an accelerated pace (Wong et al. 1972). Gong et al. (2003) also reported that application of Si improved water economy and increased the growth of plants under water stress condition.

Increase in evapotranspiration as result of thermal stress (Valipour 2015a; Khoshravesh et al. 2015) could lead to a reduction in the rate of photosynthesis (Almeselmani and Deshmukh 2012). Late planted wheat decreased the photosynthetic rate that was associated with higher evapotranspiration (Valipour 2015b) and stomatal conductance (Takahashi and Nakaseko 1992). Many studies described that high temperature reduced the photosynthetic rate by accelerating the leaves senescence in wheat (Guttieri et al. 2001; Rahman et al. 2005; Pourreza et al. 2009), maize (Valentinuz and Tollenaar 2004) and rice (Hong et al. 1999; Xie et al. 2011).

Soil applied Si significantly increased the photosynthetic rate, decreased the transpiration rate in late sown wheat. This might be attributed to improved water uptake, root growth, and leaf erectness by application of Si (Gong et al. 2003; Hattori et al. 2005) and reduced the evapotranspiration which maintain water status of plant (Valipour and Eslamian 2014; Valipour 2014) and improved higher photosynthesis. Previously, Gong et al. (2003) reported that addition of $\mathrm{Si}$ in soil increased photosynthetic rate drought conditions. Accumulation of silicon in the leaves increases leaf blade erectness, which in turns facilitates light penetration, decreases transpiration, and promotes photosynthesis.

It is evident from present study that different sowing dates significantly influenced the protein and defense mechanism like SOD and CAT activities in the flag leaf at heading stage of wheat (Fig. 3). If the defense mechanism against oxidative stress is not sufficient, plant may become susceptible to ROS damage (Pell and Dann 1991). Reactive oxygen species (ROS) in crop plants are eliminated by the variety of enzymatic and non-enzymatic 
antioxidants which is most proficient against oxidative stress (Halliwell and Gutteridge 1999; Liang et al. 2006). High temperature stress induced oxidative stress and expression of antioxidants in crop plants was reported by many researchers (Panchuk et al. 2002; Kochhar and Kochhar 2005). Antioxidants' enzymes productions is triggered by the increased level of ROS which are produced when the cellular homeostasis is disrupted (Badawi et al. 2007). It could be stated that the higher SOD activity is the part of the ability to tolerate high temperature. In this present study, soil applied Si significantly increased the SOD and CAT activity. It indicated that the oxidative damage due to high temperature in late sown wheat was ameliorated by $\mathrm{Si}$ application due to the remarkable increase of SOD and CAT and decrease of $\mathrm{H}_{2} \mathrm{O}_{2}$ content (Liang et al. 1996; Gong et al. 2008). Gong et al. (2005) reported that application of Si on wheat under water stress conditions also enhanced the activities of SOD, CAT and reduced the activity of $\mathrm{H}_{2} \mathrm{O}_{2}$. In addition, exogenous application of Si significantly increased soluble protein content of maize seedlings under salt stress (Liang 1998; Moussa 2006; Al-aghabary et al. 2004). The $\mathrm{Si}$ is able to increase soluble protein content of plants leaves, which helps plants to overcome stress by replacing the lost soluble protein content under stressful environment (Zhu et al. 2004). Finding of our study is in line with the results of Almeselmani et al. (2006) who also reported that Si application on wheat significantly increased the activities of SOD and CAT under stressful conditions. Application of Si increased antioxidant activities of plants and thereby alleviate ROS damage induced by stresses such as salt (Liang et al. 2003; Zhu et al. 2004; Qian et al. 2006) and drought (Gong et al. 2005; Li et al. 2007). Liang et al. (2008) reported that silicon enhanced the resistance against stress in winter wheat by increasing the enzymatic antioxidants activity.

In conclusion, water relations (RWC, water potential, osmotic potential and turgor potential), photosynthetic rate concentration, enzymatic antioxidants activity (SOD and CAT) of flag leaf improved significantly by soil applied Si at heading stage under early and late sown conditions. The addition of Si may act to alleviate high temperature stress under late sown wheat by improving and maintaining the membrane integrity and water status of the wheat plants. A significant increase in antioxidant enzymes of flag leaves of wheat by Si application that may be involved in the metabolic or physiological activity of wheat sown under late sown conditions. We can suggest that soil applied Si at heading stage may ameliorate the adverse effects of high temperature in late sown wheat.

\section{Acknowledgements}

First author is really thankful to Higher Education Commission, Govt. of Pakistan, for providing the financial support for conducting the $\mathrm{PhD}$ research in the form of Indigenous 5000 fellowship.

\section{References}

Agarie, S., Uchida, H., Agata, W., Kubota, F., Kaufman, P.B. 1998. Effects of silicon on transpiration and leaf conductance in rice plants (Oryza sativa L.). Plant Prod. Sci. 1:89-95. 
Al-aghabary, K., Zhu, Z., Qinhua, S. 2004. Influence of silicon supply on chlorophyll content, chlorophyll fluorescence, and antioxidative enzyme activities in tomato plants under salt stress. J. Plant Nutr. 27:21012115.

Almeselmani, M., Deshmukh, P.S., Sairam, R.K., Kushwaha, S.R., Singh, T.P. 2006. Protective role of antioxidant enzymes under high temperature stress. Plant Sci. 171:382-388.

Almeselmani, M., Deshmukh, P.S. 2012. Effect of high temperature stress on physiological and yield parameters of some wheat genotypes recommended for irrigated and rainfed condition. Jordan J. Agric. Sci. 8:66-77.

Anon, S., Fernandez, J.A., Franco, J.A., Torrecillas, A., Alarcón, J.J., Sánchez-Blanco, M.J. 2004. Effects of water stress and night temperature preconditioning on water relations and morphological and anatomical changes of Lotus creticus plants. Hort. Sci. 101:333-342.

Badawi, M., Reddy, Y.V., Agharbaoui, Z., Tominaga, Y., Danyluk, J., Sarhan, F., Houde, M. 2007. Structure and functional analysis of wheat ICE (Inducer of CBF Expression) genes. Plant Cell Physiol. 48:1237-1249.

Barrs, H.D., Weatherley, P.E. 1962. A re-examination of the relative turgidity technique for estimating water deficits in leaves. Aust. J. Biol. Sci. 15:413-428.

Berry, J.A., Raison, J.K. 1981. Responses of macrophytes to temperature. In: Lange, O.L., Nobel, P.S., Osmond, C.B., Ziegler, H. (eds), Encyclopedia of Plant Physiology, Physiological Plant Ecology, New Series, Vol 12A. Springer. New York, USA. pp. 277-338.

Bradford, M. 1976. A rapid and sensitive method for the quantitation of microgram quantities of protein utilizing the principle of protein-dye binding. Ann. Biochem. 72:248-254.

Chance, M., Maehly, A.C. 1955. Assay of catalases and peroxidases. Methods Enzymol. 2:764.

Epstein, E. 1999. Silicon. Ann. Rev. Plant Physiol. 50:641-664.

Giannopolitis, C.N., Ries, S.K. 1977. Superoxide dismutase I. Occurrence in higher plants. Plant Physiol. 59:309-314.

Gong, H.J., Chen, K.M., Chen, G.C., Wang, S.M., Zhang, C.L. 2003. Effect of silicon on growth of wheat under drought. J. Plant Nutr. 26:1055-1063.

Gong, H., Zhu, X., Chen, K., Wang, S., Zhang, C. 2005. Silicon alleviates oxidative damage of wheat plants in pots under drought. Plant Sci. 169:313-321.

Gong, H.J., Chen, K.M., Zhao, Z.G., Chen, G.C., Zhou, W.J. 2008. Effects of silicon on defense of wheat against oxidative stress under drought at different developmental stages. Biol. Plantarum 52:592-596.

Guttieri, M.J., Stark, J.C., Obrien, K., Souza, E. 2001. Relative sensitivity of spring wheat grain yield and quality parameters to moisture deficit. Crop Sci. 41:327-335.

Halliwell, B., Gutteridge, J.M.C. 1999. Free Radicals in Biology and Medicine. Clarendon Press, Oxford University Press. Oxford, New York.

Hattori, T., Inanaga, S., Araki, H., An, P., Morita, S., Luxova, M., Lux, A. 2005. Application of silicon enhanced drought tolerance in Sorghum bicolor. Physiol. Plant 123:459-466.

Hong, S.S., Hong, T., Jiang, H., Xu, D.Q. 1999. Changes in the non-photochemical quenching of chlorophyll fluorescence during aging of wheat flag leaves. Photosynthetica 36:621-625.

Hussain, M., Shabir, G., Farooq, M., Jabran, K., Farooq, S. 2012b. Developmental and phenological responses of wheat to sowing dates. Pak. J. Agri. Sci. 49:459-468.

Hussain, M., Farooq, M., Shabir, G., Khan, M.B., Zia, A.B., Lee, D.D. 2012a. Delaying planting decreases wheat productivity. Int. J. Agric. Biol. 14:533-539.

Iqbal, M., Khan, M.A., Anwar, M.Z. 2002. Zero-tillage technology and farm profits: a case study of wheat growers in the rice zone of Punjab. Pak. Dev. Rev. 41:665-682.

Kochhar, S., Kochhar, V.K. 2005. Expression of antioxidant enzymes and heat shock protein in relations to combine stress of cadmium and heat in Vigna mungo seedlings. Plant Sci. 168:921-929.

Khoshravesh, M., Sefidkouhi, G.M.A., Valipour, M. 2015. Estimation of reference evapotranspiration using multivariate fractional polynomial, Bayesian regression, and robust regression models in three arid environments. Appl. Water Sci. 5:122-132.

Li, Q.F., Ma, C.C., Shang, Q.L. 2007. Effects of silicon on photosynthesis and antioxidative enzymes of maize under drought stress. Chinese J. Appl. Ecol. 18:531-536. 
Liang, Y., Chen, Q., Zhang, W., Ding, R. 2003. Exogenous silicon increases antioxidant enzyme activity and reduces lipid peroxidation in root of salt-stressed barley (Hordeum vulgare L.). Plant Physiol. 160:11571167.

Liang, Y., Zhang, W., Chen, Q., Liu, Y., Ding, R. 2006. Effect of exogenous silicon (Si) on H-ATPase activity, phospholipids and fluidity of plasma membrane in leaves of salt-stressed barley (Hordeum vulgare L.). Environ. Exp. Bot. 57:212-219.

Liang, Y., Sun, W., Zhu, Y.G., Christie, P. 2007. Mechanisms of silicon-mediated alleviation of abiotic stresses in higher plants: a review. Environ. Pollut. 147:422-428.

Liang, Y.C., Shen, Q.R., Shen, Z.C., Ma, T.S. 1996. Effects of silicon on salinity tolerance in barley cultivars. J. Plant Nutr. 19:173-183.

Liang, Y.C. 1998. Effects of Si on leaf ultrastructure, chlorophyll content and photosynthetic activity in barley under salt stress. Pedosphere 34:289-296.

Liang, Y.C., Zhu, J., Li, Z.J. 2008. Role of silicon in enhancing resistance to freezing stress in two contrasting winter wheat cultivars. Environ. Exp. Bot. 64:286-294.

Liu, X., Huang, B. 2000. Heat stress injury in relation to membrane lipid peroxidation in creeping bentgrass. Crop Sci. 40:503-509.

Ma, J.F., Yamaji, N. 2006. Silicon uptake and accumulation in higher plants. Trends Plant Sci. 11:392-397.

Mazorra, L.M., Nunez, E., Echerarria, M., Coll, F., Sánchez-Blanco, M.J. 2002. Influence of brassinosteriods and antioxidant enzymes activity in tomato under different temperatures. Plant Biol. 45:593-596.

Mittler, R., Vanderauwera, S., Gollery, M., Van Breusegem, F. 2004. Reactive oxygen gene network of plants. Trends Plant Sci. 9:490-498.

Moussa, H.R. 2006. Influence of exogenous application of silicon on physiological response of salt-stressed maize (Zea mays L.). Int. J. Agric. Biol. 2:293-297.

Panchuk, Volkov, R.A., Schoffl, F., 2002. Heat stress and heat shock transcript factor-dependent expression and activity of ascorbate peroxidase in Arabidopsis. Plant Physiol. 129:838-853.

Pell, E.J., Dann, M.S. 1991. Multiple stress and plant senescence. In: Mooney, H.A., Winner W.E., Pell, E.J. (eds), Integrated Response of Plants to Stress. Academic Press. San Diego, CA, USA. pp. 189-204.

Pourreza, J., Soltani, A., Naderi, A., Aynehband, A. 2009. Modelling leaf production and senescence in wheat. American-Eurasian J. Agric. Environ. Sci. 6:498-507.

Qian, Q.Q., Zai, W.S., Zhu, Z.J., Yu, J.Q. 2006. Effects of exogenous silicon on active oxygen scavenging systems in chloroplasts of cucumber (Cucumis sativus L.) seedlings under salt stress. J. Plant Physiol. Mol. Biol. 32:107-112.

Rahman, M.A., Chikushi, J., Yoshida, S., Yahata, H., Yasunsga, B. 2005. Effect of high air temperature on grain growth and yields of wheat genotypes differing in heat tolerance. J. Agric. Meteorol. 60:605-608.

Ristic, Z., Bukovnik, U., Momcilovic, Fu, I.J., Prasad, P.V. 2008. Heat-induced accumulation of chloroplast protein synthesis elongation factor, EF-Tu, in winter wheat. J. Plant Physiol. 165:192-202.

Romero-Aranda, M.R., Jurado, O., Cuartero, J. 2006. Silicon alleviates the deleterious salt effect on tomato plant growth by improving plant water status. J. Plant Physiol. 163:847-855.

Sairam, R.K., Tyagi, A. 2004. Physiology and molecular biology of salinity stress tolerance in plants. Curr. Sci. 86:407-421.

Simoes-Araujo, J.L., Rumjanek, N.G., Margis-Pinheiro, M. 2003. Small heat shock proteins genes are differentially expressed in distinct varieties of common bean. Braz. J. Plant Physiol. 15:33-41.

Steel, R.G.D., Torrie, J.H., Dickey, D.A. 1997. Principles and Procedures of Statistics: A Biometric Approach, 3rd Ed. McGraw Hill Book Co. Inc. New York. USA.

Takahashi, C.Y., Nakaseko, K. 1992. Varietals differences in yield response to delayed sowing of spring wheat in Hokkaido. Japanese J. Crop Sci. 61:22-27.

Tsukaguchi, T., Kawamitsu, Y., Takeda, H., Suzuki, K., Egawa, Y. 2003. Water status of flower buds and leaves as affected by high temperature in heat tolerant and heat-sensitive cultivars of snap bean (Phaseolus vulgaris L.). Plant Prod. Sci. 6:24-27.

Vacca, R.A., De, Pinto, M.C., Valenti, D., Passarella, S., Marra, E., De Gara, L. 2004. Production of reactive oxygen species, alteration of cytosolic ascorbate peroxidase, and impairment of mitochondrial metabolism 
are early events in heat shock-induced programmed cell death in tobacco Bright-Yellow 2 cells. Plant Physiol. 134:1100-1112.

Valentinuz, O.R., Tollenaar, M. 2004. Vertical profile of leaf senescence during the grain-filling period in older and new maize hybrids. Crop Sci. 44:827-834.

Valipour, M., Eslamian, S. 2014. Analysis of potential evapotranspiration using 11 modified temperaturebased models. Int. J. Hydro. Sci. Technol. 4:192-207.

Valipour, M. 2014. Analysis of potential evapotranspiration using limited weather data. Appl. Water Sci. 4:113-120.

Valipour, M. 2015a. Calibration of mass transfer-based models to predict reference crop evapotranspiration. Appl. Water Sci. 5:239-248.

Valipour, M. 2015b. Temperature analysis of reference evapotranspiration models. Meteorol. Appl. 22:385394.

Wahid, A., Close, T.J. 2007. Expression of dehydrins under heat stress and their relationship with water relations of sugarcane leaves. Biol. Plant 51:104-109.

Wardlaw, I.F., Blumenthal, C., Larroque, O., Wrigley, C.W. 2002. Contrasting effects of chronic heat stress and heat shock on kernel weight and flour quality in wheat. Funct. Plant Biol. 29:25-34.

Wong, Y.C., Heits, A., Ville, J.D. 1972. Foliar symptoms of silicon deficiency in the sugarcane plant. Proc. Cong. Int. Soc. Sugarcane Technol. 14:766-776.

Xie, X.J., Shen, S.H.H., Li, Y.X., Zhao, X.Y., Li, B.B., Xu, D.F. 2011. Effect of photosynthetic characteristic and dry matter accumulation of rice under high temperature at heading stage. Afr. J. Agric. Res. 6:19311940.

Xu, S., Li, J., Zhang, X., Wei, H., Cui, L. 2006. Effects of heat acclimation pretreatment on changes of membrane lipid peroxidation, antioxidant metabolites, and ultra-structure of chloroplasts in two cool-season turfgrass species under heat stress. Environ. Exp. Bot. 56:274-285.

Zekri, M. 1991. Effects of $\mathrm{NaCl}$ on growth and physiology of sour orange and Cleopatra mandarin seedlings. Sci. Hortic. 47:305-315.

Zhu, Z., Wei, G., Lia, J., Qiana, Q., Yu, J. 2004. Silicon alleviates salt stress and increases antioxidant enzymes activity in leaves of salt-stressed cucumber (Cucumis sativus L.). Plant Sci. 167:527-533. 